\title{
PENYULUHAN MEDIA SOSIAL DALAM RANGKA MENINGKATKAN EFEKTIFITAS DAN EFISIENSI PEMBANGUNAN RUMAH TAHFIDZ AL-HIKAM PADA MASA PANDEMI COVID-19
}

\author{
Lina Nofiana ${ }^{1}$, Rizka Wahyuni Amelia ${ }^{2}$, Siska Yunanti ${ }^{3}$, Mitri Nelsi ${ }^{4}$, \\ Mada Faisal Akbar ${ }^{5}$ \\ Universitas Pamulang \\ dosen02608@unpam.ac.id
}

\begin{abstract}
This activity aims to motivate and provide community counseling in managing and thinking about effective governance on solutions to develop the potential of the students to take advantage of social media as an effort to achieve the goal of building the economy for the tahsin and tahfid alhikam houses. The program we are proposing is Social Media Counseling in the Context of Increasing the Effectiveness and Efficiency of the Construction of the Tahfidz Al-Hikam House During the Covid-19 Pandemic. The form of this program is community development in utilizing technology and internet marketing, social media, which has a positive impact on students and teachers of the tahfids and this al-hikam houses to be able to open entrepreneurs. The methods that will be used in achieving the goals are various methods such as lectures, discussions and questions and answers, as well as regular community assistance. This program has long-term goals based on several forms of service, namely realizing a business and the ability to trade online for supplies in the future.
\end{abstract}

Keywords: Social Media, Effectiveness, Efficiency, Covid.

\begin{abstract}
ABSTRAK
Kegiatan ini bertujuan untuk memotivasi dan memberikan penyuluhan masyarakat dalam mengelola dan memikirkan tata kelola yang efektif tentang solusi mengembangkan potensi para santri untuk memanfaat sosial media sebagai upaya pencapaian tujuan untuk membangun perekonomian untuk rumah tahsin dan tahfid al - hikam. Program yang kami usulkan adalah Penyuluhan Media Sosial Dalam Rangka Meningkatkan Efektifitas dan Efisiensi Pembangunan Rumah Tahfidz Al-Hikam Pada Masa Pandemi Covid-19. Bentuk dari program ini adalah pengembangan masyarakat dalam memanfaatkan teknologi dan internet marketing sosial media yang dampak positifnya bagi para santri maupun tenaga pengajar para rumah tahfids dan tahsin al-hikam untuk mampu membuka wirausaha. Metode yang akan dipakai dalam pencapaian tujuan yaitu dengan berbagai metode seperti ceramah, diskusi dan tanya jawab, serta pendampingan bagi masyarakat secara rutin. Program ini mempunyai tujuan jangka panjang berdasarkan beberapa bentuk pengabdian yakni mewujudkan sebuah usaha dan kemampuan untuk berdagang secara online untuk perbekalan di masa yang akan datang.
\end{abstract}

Kata Kunci : Media Sosial, Efektifitas, Efesiensi, Covid. 


\section{A. PENDAHULUAN}

Pandemi virus Corona telah membawa dampak yang cukup terasa bagi pelaku usaha di seluruh dunia. Termasuk di Indonesia. Kebanyakan pelaku usaha terpaksa menghentikan aktifitas usahanya, karena kebijakan yang dikeluarkan pemerintah. Tak bisa dipungkiri Covid-19 telah mengubah kehidupan banyak orang dan menciptakan berbagai kebiasaan baru. Salah satu dampak yang sangat terasa adalah perubahan ekonomi di berbagai sektor. Dampak perubahan tersebut ada sebagian orang yang mengalami Pemutusan Hubungan Kerja (PHK) atau kehilangan pendapatan. Di sisi lain, perkembangan teknologi yang pesat dan jaringan internet membawa berkah tersendiri karena di masa krisis seperti sekarang mampu memberikan dampak positif yakni bermunculan berbagai peluang usaha online yang bisa ditekuni hal inilah yang akan di terapkan di rumah tahfid dan tahsin Yayasan al-hikam yang beralamat J1. Pondok kacang timur Tangerang selatan.

Sebagaimana kegiatan bisnis pada umumnya, bisnis online juga tidak lepas dari pengawasan hukum. Sebenarnya banyak undang-undang yang terkait dengan bisnis online, seperti: Undang-Undang no. 7 Tahun 2014 tentang Perdagangan mengatur segala sesuatu tentang perdagangan. Sebagai salah satu bentuk perdagangan yang dilakukan dengan media internet, tentu saja Undang-undang perdagangan mengatur hal tersebut. Pemerintah Republik Indonesia, dalam hal ini Kementerian Perdagangan, membuat Undang-Undang Perdagangan dengan maksud untuk memajukan sektor perdagangan di Indonesia. Dalam pasal 2 (a) UU no. 7 tahun 2014 tentang Perdagangan disebutkan bahwa "Kebijakan perdagangan disusun berdasarkan asas kepentingan nasional". Dalam hal ini, kepentingan nasional tentu saja meliputi pertumbuhan ekonomi, peningkatan daya saing perdagangan, melindungi produksi dalam negeri serta penguatan UMKM dan lain sebagainya.

Di zaman modernisasi seperti sekarang ini, mendidik anak membutuhkan strategi dan trik yang tepat dengan usia mereka. Karena mereka lebih paham tentang tekhnologi seperti gadget dibanding orangtuanya. Anak sholeh yang berbakti kepada orang tua serta rajin membaca Al-Qur'an merupakan dambaan setiap orang tua. Karena anak yang sholeh/hah adalah anak yang mampu menjadi Qurrotul 'Ain (penyejuk pandangan bagi orangtuanya). Suasana rumah akan terasa nyaman tenang dan damai dengan sejuknya nuansa rumah Qur'ani yang dihiasai oleh suara merdu anak-anak tatkala mereka melantunkan huruf demi huruf, kata demi kata dari ayat-ayat suci Al-Qur'an. Namun, terkadang semua kesenangan dan keindahan anak sholeh tersebut hanya sebatas khayalan dan angan-angan semata, lantaran terkendala dengan berbagai dan banyak hal, baik perkara yang bersifat intern maupun ekstern. Oleh karena itu, menjadi salah satu solusi bagi kita untuk mewujudkan citacita dan harapan memiliki anak yang sholeh yaitu dengan mencarikan lingkungan yang baik serta guru yang bertanggung jawab untuk anak-anak kita. Alhamdulillah, dengan hadirnya "Rumah Tahfidz Al-Hikam" di tengah-tengah masyarakat di kecamatan Pondok Aren diharapkan bisa menjadi solusi bagi orang tua yang menginginkan anak-anaknya menjadi penghafal Al Qur'an. Anak- anak yang mencintai Al Qur'an dan dicintai Al Qur'an, agar mereka berguna bagi keluarganya, masyarakat, bangsa, dan negara.

\section{B. METODE PELAKSANAAN KEGIATAN}

Kegiatan Pengabdian Masyarakat ini dilaksanakan secara langsung di tempat kegiatan, pada Sabtu 03-04 Oktober 2020, sekaligus memperkenalkan teknologi kepada para santri dan santriwati serta tenaga pengajar setempat. Secara lengkap metode kegiatan disajikan secara lengkap melalui penjelasan dibawah ini: 
1. Survei Tempat Pelaksanaan Kegiatan

Kegiatan ini dimaksudkan untuk menggali informasi tentang kondisi geografis dan kondisi masyarakat didaerah tempat kegiatan. Informasi tersebut berupa lokasi, permasalahan yang dihadapi dalam pada lokasi tersebut

2. Persiapan Sarana dan Prasarana.

Kegiatan ini dimaksudkan untuk merencanakan kebutuhan baik sarana dan prasarana yang akan digunakan dalam pelaksanaan kegiatan dengan tetap memperhatikan kebutuhan masyarakat secara umum dan khusus demi tercapainya target pengabdian kepada masyarakat. Sarana dan prasarana yang dimaksud berupa projektor, spanduk daln lain-lain.

3. Pelaksanaan Kegiatan.

Setelah melakukan survey dan persiapan sarana dan prasarana maka pelaksanaan kegiatan dilaksanakan oleh pengusul besrta anggota dan beberapa mahasiswa. Kegiatan yang dilakukan adalah berupa pelatihan atau penyuluhan dalam bentuk pertemuan secara langsung dengan para santri dan santriwati serta tenaga pengajar pada rumah tahsin al hikam, pondok kacang timur, tangerang selatan

4. Monitoring dan Evaluasi.

Kegiatan ini dimaksudkan untuk meninjau perkembangan aktualisasi masyarakat terhadap kegiatan yang telah dilakukan sebelumnya dengan harapan dapat dilaksanakan sesuai dengan teori yang telah di peroleh melalui kegiatan yang telah dilaksanakan. Evaluasi juga bertujuan untuk memahami pola pemahaman masyrakat terhadap informasi atau pengetahuan baru yang diperoleh dari pelaksana kegiatan. Hasil ini diharapkan mampu menjadi dasar pengembangan para santri dan santriwati pada rumah tahsin al hikam, Pondok Kacang Timur, Tangerang Selatan untuk menghetahui tata cara memasarkan produk melalui online.

\section{HASIL DAN PEMBAHASAN}

Peserta yang hadir sebanyak 25 warga masyarakat yang terdiri dari perwakilan ketua Yayasan tahsin al hikam dan para santri satriwati serta tenaga oengajar, para dosen dan Mahasiswa Universitas Pamulang. Kegiatan dilaksanakan melalui diskusi tanya jawab, dengan cara para narasumber memberikan penyuluhan dan diikuti oleh para peserta yang kumpul di Aula rumah tahsin dan tahfidz al-HIkam yang antusias menyimak menggunakan sebuah laptop yang disambungan ke LCD. Kegiatan berjalan baik dan lancar, banyaknya peserta yang antusias untuk bertanya,berdiskusi dan praktek langsung menggunakan media sosial untuk mempromosikan produk melalui online yang menjadikan para nara sumber lebih bersemangat lagi untuk memberikan penyuluhan.

Penggunaan teknologi digital berupa media sosial telah memengaruhi semua aspek termasuk aspek promosi tempak wisata yang memang sedang digalakkan oleh pemerintah setempat, tentu tidak terlepas dukungan warga masyarakat sekitar khususnya para santri dan santriwati rumah tahsin yang memang masih relatif berusia muda. Penggunaan media sosial diharapkan dapat digunakan sebagai salah satu pembuka semakin dikenal oleh dunia luas dan bisa membuka peluang usaha usaha baru juga seperti Jilbab, al quran, dan peralatan santri atau usaha lain yang nantinya akan membuka usaha berdagang secara online untuk bekal dimasa yang akan datang. Dengan adanya media sosial memungkinkan banyak calon pembeli memperoleh seluruh informasi mengenai produk melalui internet, dan memungkinkan para pembeli untuk selalu memantau dan mengikuti media sosial atau akun-akun jual beli online 
atau online shop, baik akun Instagram, Youtue, Facebook, Twiteer, Line atau akun-akun yang lain yang dikelola.

Model promosi melalu media sosial sesuai dengan perkembangan teknologi komunikasi dan informasi saat ini. Dengan diadakan pelatihan promosi melalu media sosial peserta penyuluahn nantinya dituntut lebih aktif dalam dalam mengelola akun-akun media sosialnya agar produk yang akan dijual mampu bersaing di pasar online. Diera digital promosi produk memang tidak cukup hanya dilakukan melalui media tradisional atau pun konvensional. Media konvensional adalah media yang berbayar, misalkan iklan luar ruang, seperti baliho, billboard, brosur, leaflet, iklan di media cetak, radio, dan juga televisi. Media-media tersebut dinilai berbiaya tinggi, tidak interaktif, kurang dapat diperbaharui setiap saat, dan sulit diprediksi efektivitasnya. Selain itu, tidak dapat diketahui secara langsung respons, minat beli masyarakat menurun.

Promosi yang biasanya hanya menggunakan media tradisioanl yaitu melalui mulut ke mulut, poster atau pamplet, kini berubah menjadi promosi melalui media sosial yang bias dilakukan dimana saja kapan saja dan siapa saja, entah itu di rumah di sekolah di tempat kerja atau bahkan di tempat-tempat privasi sekalipun, dan bias dilakukan oleh tua, muda, semua kalangan orang kota orang desa sekolah maupun pondok santri siswa maupun santri. Perubahan metode promosi akan semakin berkempang pesat, jika media sosial tersebut dikeloa dengan baik, serta menggunakan trik atau cara cara jitu agar promosi tepat sasaran yaitu menyembar dengan cepat dan tepat. Segmen yang tepat tentu tidak akan membuat siasia promosi menggunakan media social.

\section{KESIMPULAN DAN SARAN}

\section{Kesimpulan}

Hasil kegiatan PKM di rumah tahsin di lokasi berjalan dengan lancar. Meski pada masa PSBB namun dengan tetap melaksankan protocol sesuai anjuran pemerintah setempat Perserta terlihat antusias mengikuti pemyuluhan walau keterbatasan sarana prasana. Penyuluhan sosial media memberikan kemudahan masyarakat dalam melakukan kegiatan yang positif dan inovatif agar lebih dikenal masyarakat luas sehingga dapat menumbuhkan semangat berwirausaha untuk paraa santri dan santriwati pada rumah tahsin dan tafidh alhikam.

\section{Saran}

Berikut adalah beberapa saran untuk Yayasan rumah tahsin dan tahfids al-hikam setempat maupun masyarakat dalam meningkatkan potensi diri para santri dan santriwati di rumah tahsin al-hikam:

1. Membuat akun media sosial sebagai media terpisah dari akun pribadi.

2. Penggunaan media social sangat bermanfaat untuk membuat sebuah inovasi atau sebuah usaha untuk memajukan kehidupan para santriwan san santriwati dalam memasarkan produk ataupun hal lain.

3. Usahakan setiap posting foto dan kegiatan yang berkaitan dengan rumah tahsin al-hikam memberikan tanda pagar (hashtag) sebagai kata kunci dan tag ke akun akun yang mempunyai banyak follower.

4. Menjawab segala pertanyaan dari follower untuk menandakan bahwa akun aktif. 


\section{DAFTAR PUSTAKA}

Alma, (2013), Manajemen Pemasaran Dan Pemasaran Jasa, CV Alfabeta, Bandung.

Arikunto, Suharsimi (2010), Prosedur Penelitian: Suatu Pendekatan Praktis. Edisi Revisi, Rineka Cipta. Jakarta

Ariyanto, A., Sudarsono, A., Ivantan, I., Akbar, M. F., \& Munarsih, M. (2020). Pengembangan Potensi Destinasi Wisata Curug Angkrek melalui Media Sosial di Kp. Cimuncang, Desa Karangnunggal, Kabupaten Tasikmalaya Jawa Barat. BAKTIMAS: Jurnal Pengabdian pada Masyarakat, 2(2), 95-99.

Ariyanto, Aris 2019, The Influence of Price and Service Quality on Customer Satisfaction at PT Sarana Estate

Assauri, 2012, Manajemen Pemasaran, Rajawali Pers, Jakarta.

Atik dan Ratminto, 2012, Manajemen Pelayanan. Pustaka Pelajar, Yogyakarta.

Daryanto, 2011, Strategi Menaklukkan. Pasar Melalui Riset Ekuitas dan Perilaku Merek. Cetakan Ketiga. Gramedia, Jakarta.

Effendi M. Guntur, 2010, Transformasi Manajemen Pemasaran+Membangun. Citra Negara. Sagung Seto, Jakarta.

Ghozali, 2012, Aplikasi Analisis Multivariate Dengan Program SPSS. Badan Penerbit Undip. Semarang.

Hasan, 2009, Marketing, Media Pressindo, Yogyakarta.

Hasibuan, 2009, Manajemen Sumber Daya Manusia, Edisi Revisi, PT Bumi Aksara, Jakarta.

Jhon D. Millet, 2012, Management in the public service: The quest for effective performance. New York: McGraw-Hill.

Kotler dan Keller, 2012, Manajemen Pemasaran, Edisi 12, Penerjemah Benyamin Molan, Indeks, Jakarta.

Kotler dan Amstrong, 2012, Prinsip-Prinsip Pemasaran Jilid I. Erlangga, Jakarta.

Kurniali, S. (2009). Peran Media Sosial Di Internet Pada Penerapan Proses Knowledge Management. Skripsi. Program Studi Manajemen Sistem Informasi Bina Nusantara Jakarta; 8-9.

Legawa, Aby. 2008. Komponen Produk Pariwisata dengan Acuan Khusus. Jakarta: Gramedia Pustaka

Mahendrawaty, Nanih dan Agus Ahmad Syafe'i. 2001. Pengembangan Masyarakat Islam: dari ideology strategi sampai strategi. Bandung: PT.Rosdakarya

Mukhlis, Mukhamad Memasyarakatkan Shodaqoh melalui Pendidikan Agama Islam Studi Permasyarakatan Shodaqoh di PPPA Daarul Qur'an

Munarsih, M., Akbar, M. F., Ariyanto, A., Ivantan, I., \& Sudarsono, A. (2020). Pelatihan Digital Marketing Dalam Meningkatkan Kompetensi Siswa Untuk Berwirausaha Pada Smk Muhammadiyah Parung-Bogor. Jurnal Pengabdian Dharma Laksana, 3(1), 22-28.

Rangkuty, 2009, Riset Pemasaran, Gramedia pustaka Utama, Jakarta. 
Robbins dan Coulter, 2014, Manajemen, Edisi ke sepuluh jilid 1, Erlangga, Jakarta.

Rosvita, 2010, Analisis Pengaruh Kualitas Produk, Harga, Promosi, dan Cuaua terhadap Keputusan Pembelian Teh siap Minum dalam Kemasan Merek Teh Botol Sosro. Fakultas Ekonomi Universitas Diponegoro Semarang.

Rulli Nasrullah, 2016, Media Sosial Perspektif Komunikasi, Budaya, Sosioteknologi, Cet.kedua, Simbiosa Rekatama Media, Bandung

Safroni, 2012, Manajemen dan Reformasi Pelayanan Publik dalam. Konteks Birokrasi Indonesia. Aditya Media Publishing, Surabaya

Saladin, 2011, Manajemen Strategi dan Kebijakan Perusahaan, Edisi Lima, Linda Karya, Bandung.

Shinta Agustina, 2011, Perilaku Konsumen : Afeksi Konsumen, Lab, Manajemen Agribisnis/Fakultas Pertanian, Universitas Brawijaya, Malang.

Stelzner, MA (2012). Social Media Marketing Industry Report. How Marketers Are Using Social Media to Grow Their Business

Stockdale, Ahmed, \& Scheepers. (2012). Identifying Business Value from The Use of Social Media: An SME Perspective. Pacific Asia Conference on Information Systems. Association for Inforamtion System Electronic Library

Sugiyono, 2015, Metodologi Penelitian Manajemen, Alfabeta, Bandung.

Supardi, 2013, Aplikasi Statistik Dalam Penelitian, PT Prima Ufuk Semesta, Jakarta.

Supranto, 2012, Metode Riset Aplikasinya Dalam Pemasaran, Lembaga Penerbitan Fakultas Ekonomi Universitas Indonesia, Jakarta.

Swastha dan Irawan, 2011, Pemasaran Modern, Liberty, Yogyakarta.

Tjiptono, 2014, Pemasaran Jasa, Andi Offset, Yogyakarta. 